\title{
Home range and spawning migration patterns of queen triggerfish Balistes vetula in St. Croix, US Virgin Islands
}

\author{
David R. Bryan ${ }^{1,2, *}$, Michael W. Feeley ${ }^{3}$, Richard S. Nemeth ${ }^{4}$, Clayton Pollock ${ }^{5}$, \\ Jerald S. Ault ${ }^{1}$ \\ ${ }^{1}$ University of Miami, Rosenstiel School of Marine and Atmospheric Science, Department of Marine Ecosystems and Society, \\ 4600 Rickenbacker Causeway, Miami, FL 33149, USA \\ ${ }^{2}$ Pacific States Marine Fisheries Commission, 7600 Sand Point Way N.E., Seattle, WA 98115, USA \\ ${ }^{3}$ National Park Service, South Florida/Caribbean Inventory and Monitoring Network, 18001 Old Cutler Rd Suite 419, \\ Palmetto Bay, FL 33157, USA \\ ${ }^{4}$ University of the Virgin Islands, Center for Marine and Environmental Studies, 2 John Brewers Bay, St. Thomas, \\ US Virgin Islands 00802, USA \\ ${ }^{5}$ National Park Service, Buck Island National Park, 2100 Church St. \#100, Christiansted, US Virgin Islands 00820, USA
}

\begin{abstract}
Queen triggerfish Balistes vetula are an ecologically and economically important species associated with coral reefs throughout the tropical Atlantic Ocean. To better understand spatial and temporal movement patterns and help determine the effectiveness of a no-take marine reserve (Buck Island Reef National Monument, BIRNM), 55 queen triggerfish were surgically implanted with acoustic transmitters and tracked for $434.6 \pm 27.3 \mathrm{~d}$ (mean $\pm \mathrm{SE}$ ) within a large acoustic array in St. Croix, US Virgin Islands. Queen triggerfish displayed high site fidelity within the reserve during non-spawning months. Home range sizes, as measured by $95 \%$ minimum convex polygons and kernel utilization distributions, averaged $2.44 \pm 0.30$ and $3.34 \pm 0.17 \mathrm{~km}^{2}$, respectively. High site fidelity was interrupted briefly during full moons from November to March (2015-2017), when $22 \%$ of the tagged population $(\mathrm{n}=12)$ undertook repeated migrations to a nesting area located approximately $12 \mathrm{~km}$ from BIRNM. During the same-season spawning periods, 5 other fish were exclusively detected at a receiver station within the reserve, indicating a possible local nesting area and resident (non-migratory) contingent of queen triggerfish. The high site fidelity of queen triggerfish during non-spawning months coupled with the discovery of a resident spawning population highlights the importance of BIRNM as a potential refuge from local fishing pressures. This study provides improved understanding of queen triggerfish movement ecology, an extremely valuable asset for the development of spatial management strategies throughout their range.
\end{abstract}

KEY WORDS: Movement ecology · Marine reserves - Partial migration · Fisheries management · Acoustic telemetry $\cdot$ Balistidae $\cdot$ Spawning aggregation

\section{INTRODUCTION}

An understanding of the temporal and spatial extent of reef fish movement patterns is paramount to successful design of spatial management strategies (Sale et al. 2005, Botsford et al. 2009, Grüss et al.

*Corresponding author: david.bryan@noaa.gov 2011a). For example, the movement ecology of adult fish, including the location and size of home ranges, migratory pathways, and spawning areas, can influence the effectiveness of marine protected areas (Kramer \& Chapman 1999, Crossin et al. 2017). Highly mobile fish with large home ranges and extensive

(C) The authors 2019. Open Access under Creative Commons by Attribution Licence. Use, distribution and reproduction are unrestricted. Authors and original publication must be credited. 
migrations require larger protected areas to reduce exploitation in comparison to more sedentary species (Kramer \& Chapman 1999). In recent years, acoustic tracking of reef fishes has provided great insight into the spatial connectivity within tropical coral reef ecosystems and has revealed species-specific differences in home ranges and the timing and extent of migratory movements (Farmer \& Ault 2011, Hitt et al. 2011, Pittman et al. 2014a, Green et al. 2015, Hussey et al. 2015, Crisafulli et al. 2018). This information can be used in the design of marine reserves and to predict possible benefits of protected areas (Grüss et al. 2011a,b, Cornejo-Donoso et al. 2017, Weeks et al. 2017, Farmer \& Ault 2018, Krueck et al. 2018).

Queen triggerfish Balistes vetula (Balistidae) are an important food fish targeted by commercial, recreational, and artisanal fishers throughout the tropical Atlantic (Tyler \& Munroe 2015). Despite their wide geographic range and economic importance, queen triggerfish movement ecology is not well understood. Their reproductive strategy includes paired spawning, demersal eggs, territorial nests, and parental care (Kawase 2002, Clark et al. 2015). Queen triggerfish are sexually dimorphic, with $50 \%$ of males reaching sexual maturity at significantly smaller sizes ( $21.1 \mathrm{~cm}$ fork length, FL) than females (24.5 cm FL) (Hernández et al. 2019). In the Caribbean Sea, they are indeterminate batch spawners, and females may spawn up to 5 times a year (Hernández et al. 2019). In the Gulf of Mexico, male gray triggerfish $B$. capriscus build, maintain, and guard demersal nests during a summer spawning period while females tend the eggs (Simmons \& Szedlmayer 2012). Acoustic tracking and conventional tagging studies have indicated that gray triggerfish have high site fidelity and residency rates (Ingram \& Patterson 2001, Herbig \& Szedlmayer 2016). Anecdotal information also suggests that queen triggerfish aggregate at nesting sites where they reproduce (Kadison et al. 2009, Kobara et al. 2013, Hernández et al. 2019), but very little is known about their movement behaviors, including home range sizes, spawning activity, and migratory pathways.

St. Croix, United States Virgin Islands (USVI), is a relatively small, isolated, tropical island located in the northern Caribbean Sea, surrounded by coral reefs (Fig. 1). Overexploitation of local reef fish populations has been reported for decades, yet fishing remains an important economic activity on the island (Kadison et al. 2017). Queen triggerfish, which are still relatively common on the shallow reefs (Bryan et al. 2016), are a significant component of the local fishery with modest annual landings averaging $6750 \mathrm{~kg}$ on St. Croix and $20100 \mathrm{~kg}$ on St. Thomas and St. John (Sagarese et al. 2018). Sustainability status of queen triggerfish in the USVI and the effectiveness

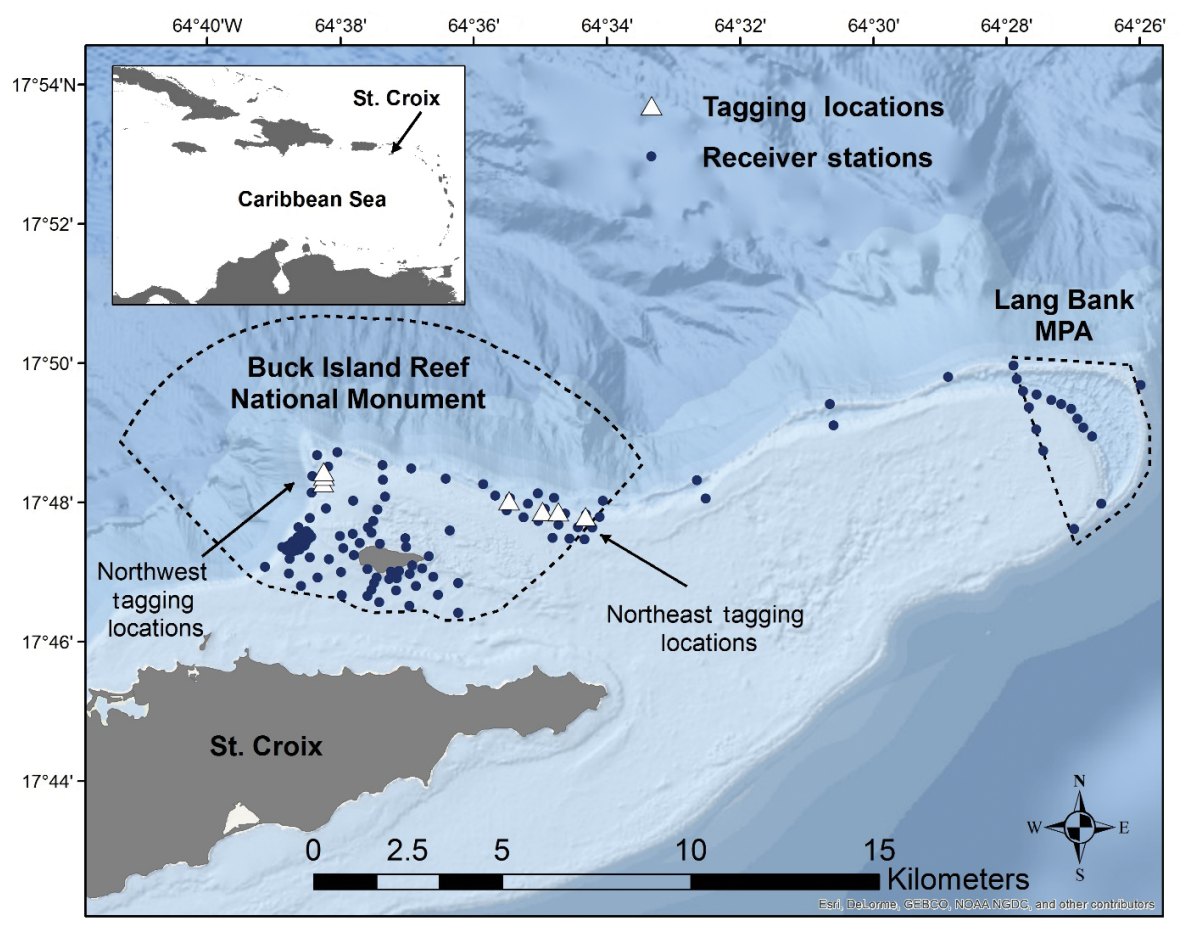

Fig. 1. East end of St. Croix, US Virgin Islands, including Buck Island Reef National Monument and the Lang Bank marine protected area (MPA) boundaries. Receiver stations are shown as dark blue circles and tagging locations as white triangles 
of current catch limits are not well understood (GarciaMoliner \& Arnold 2013, Carruthers et al. 2014, Newman et al. 2015, Sagarese et al. 2018). However, in addition to catch limits, there is a large no-take marine reserve and several smaller seasonal area closures in St. Croix that could play an important role in sustaining reef fish stocks (Russ \& Alcala 2004, Gaines et al. 2010, Ault et al. 2013, Pittman et al. 2014 b). In this study, we used a large acoustic array to monitor the spatial and temporal movements of queen triggerfish within and among these marine reserves. Improved understanding of the movement patterns of queen triggerfish can help evaluate the efficacy of marine reserves in St. Croix and guide spatial management planning throughout their range.

\section{MATERIALS AND METHODS}

\subsection{Study site and receiver stations}

Located off the northeast coast of St. Croix, USVI, Buck Island Reef National Monument (BIRNM) is a no-take marine reserve that encompasses $10 \%$ of the island's mapped coral reef habitat (Fig. 1). BIRNM contains a wide diversity of reefs ranging from shallow patch reefs to deep mesophotic ridges (Costa et al. 2012). To better understand habitat utilization and the potential connectivity of a broad range of marine taxa (e.g. sharks, conches, turtles, fishes), within and outside of BIRNM, the National Park Service, in collaboration with 11 partner agencies, established a relatively large acoustic array in 2014 that consisted of 111 stations equipped with VR2W ${ }^{\circledR}$ passive acoustic receivers (Vemco) located in a variety of habitats in depths ranging from 2 to $40 \mathrm{~m}$ (Becker et al. 2016, Selby et al. 2016) (Fig. 1). Thirty of the 111 stations were specifically located in the northwestern and northeastern regions of BIRNM, where queen triggerfish are common. In addition to the BIRNM acoustic array, from 2014 to 2017 researchers at the University of the Virgin Islands (UVI) also maintained a seasonal (November-April) array of 10 to $16 \mathrm{VR} 2 \mathrm{~W}^{\circledR}$ receivers at Lang Bank in depths of 14-48 m. Lang Bank is a submerged hardbottom platform located $12 \mathrm{~km}$ east of BIRNM and is a known fish spawning aggregation site for queen triggerfish and red hind Epinephelus guttatus (Nemeth et al. 2007); this area is closed to all fishing from December 1 until February 28 each year and closed to trap fishing all year.

All receivers in the 2 arrays (BIRNM and Lang Bank) were anchored semi-permanently to the sea floor with either cement blocks or sand screws de- pending on the substrate type. Receivers at deeper stations $(>15 \mathrm{~m})$ were pointed downward and suspended $5 \mathrm{~m}$ off the bottom with a line attached to a buoy, whereas those at shallower stations $(\leq 15 \mathrm{~m})$ were placed $0.5 \mathrm{~m}$ off the bottom and pointed upward. During the course of the study, individual stations were visited every 6 mo to download the data recorded on the receiver, replace batteries, and to inspect and maintain the anchoring tackle.

\subsection{Range testing}

In 2016, we performed a range test on 6 receiver stations in the northwest and northeast regions of the BIRNM array, across a variety of habitat types (i.e. pavement, sand, rhodolith beds, and spur and groove) (Fig. 2). Range tests were conducted during daylight hours with typical weather conditions and sea state for BIRNM. Fixed delay V9-2L tags (Vemco) with $60 \mathrm{~s}$ intervals were used for the range testing. Each tag was placed $2 \mathrm{~m}$ off the bottom, to replicate the typical height queen triggerfish that were observed swimming off bottom, at $50 \mathrm{~m}$ increments up to $350 \mathrm{~m}$ from the targeted station and left for $1 \mathrm{~h}$. A detection rate for each distance from the station was calculated by dividing the total number of observed detections by the expected number of detections based on the ping rate and the duration of the deployment. We modeled the detection rates at each station and distance combination with a logistic regression, specifically a generalized linear model with a binomial distribution and logit link function in R (Welsh et al. 2012, Farmer et al. 2013, R Core Team 2016). Estimates of the distances (m) for 50, 25, and $10 \%$ detection probabilities within the array were calculated.

\subsection{Acoustic tags}

To minimize handling and barotrauma stress and avoid unwanted bycatch, queen triggerfish were targeted with underwater hook-and-line methods and tagged in situ, which ensures a high survival rate (Tuohy et al. 2015). Fish were captured with small 1/0 circle hooks tied to $1 \mathrm{~m}$ of $30 \mathrm{lb}$ fluorocarbon leader attached a spool of abrasion-resistant Dacron line. Hooks were baited with small sections of previously frozen ballyhoo Hemiramphus brasiliensis. At each tagging site, scuba divers attracted queen triggerfish into the area by spreading out pieces of chopped bait. Shortly after fish began to aggressively feed, a diver placed a baited hook into the area where fish 

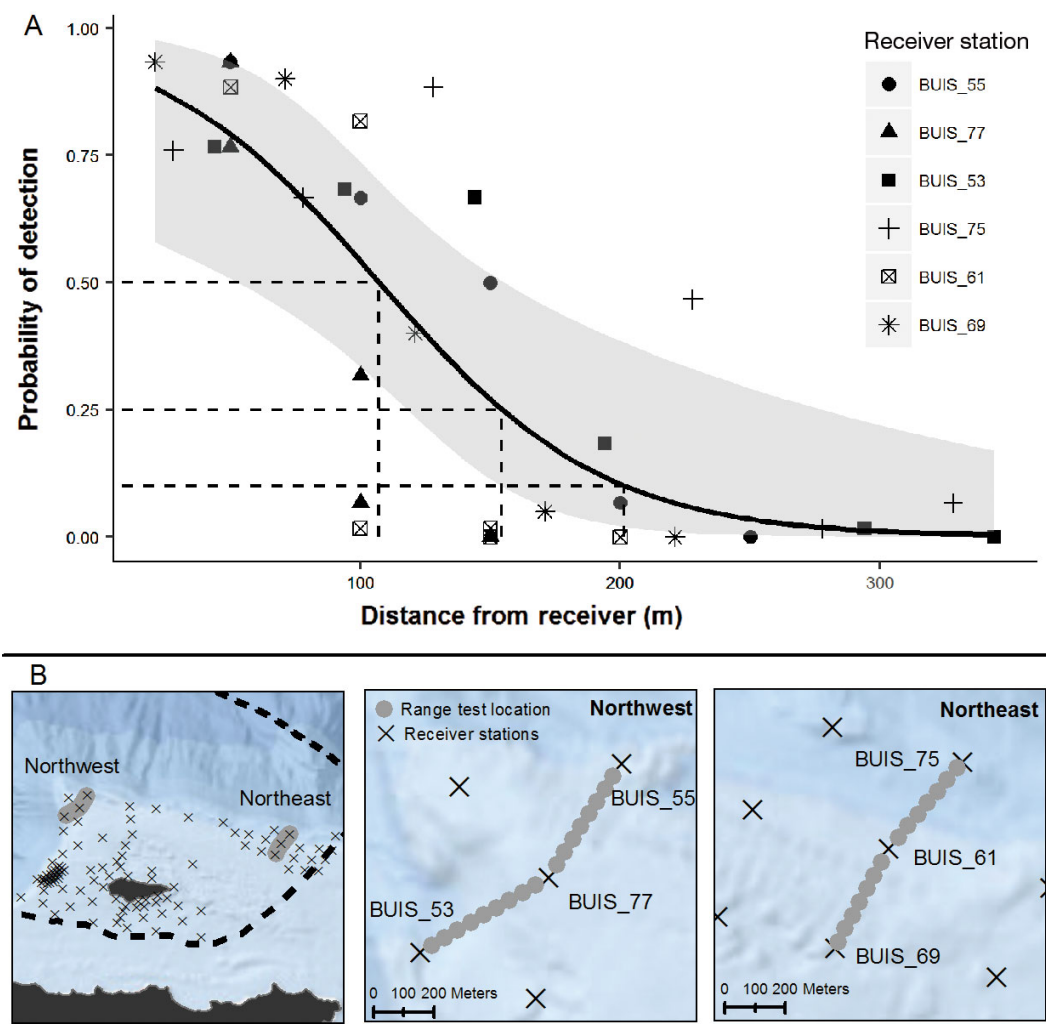

Fig. 2. (A) Probability of detection by distance for all range tests fit with a generalized linear model (black line). Gray shading represents the 95\% confidence interval of the model predictions. Dashed lines indicate the predicted distance at $50 \%(107 \mathrm{~m}), 25 \%(154 \mathrm{~m})$ and $10 \%(201 \mathrm{~m})$ detection probabilities. (B) Location of range testing sites in the northwest and northeast regions of Buck Island Reef National Monument (dark dashed line)

Tagging locations were chosen based on habitat maps and known distributions of queen triggerfish; these were typically at $25 \mathrm{~m}$ depth. Tagging locations were divided into 2 general areas, the northwest and northeast regions of BIRNM (Fig. 1). Tagging took place in April 2015 and February and March 2016. Habitat in both locations was similar and consisted of low-relief reef pavement mixed with areas of unconsolidated sediments and rhodolith beds. In the northwest region, the reef had a patchy distribution with a high percent of soft coral coverage. In the northeast region, the reef was linear with minimal biotic cover.

\subsection{Analyses}

Acoustic detections from tagged fish were processed and summarized in the $\mathrm{R}$ programming environment ( $\mathrm{R}$ Core Team 2016). An estimate of array fidelity within BIRNM was calculated by dividing the number of days that a fish was detected by the total number of days between the first and last detection. The analysis of queen triggerfish movement and home ranges was di-

were feeding. All fish were hooked in the lip by slowly pulling in the line when fish began to feed on the bait. Once hooked, queen triggerfish were quickly pulled in and confined within a large nylon net where the surgery took place.

Due to their relatively small abdominal cavity, V92L coded transmitters (Vemco) with a $9 \mathrm{~mm}$ diameter and $29 \mathrm{~mm}$ length were used to tag all queen triggerfish. Transmitter power output was set to low, and each tag was programmed with a 90-180 s delay to provide an average battery life of $802 \mathrm{~d}$.

Once confined within the nylon net, fish were positioned ventral side up to provide partial immobilization during surgery. The hook was carefully removed from their lip with a hemostat. A small $(<2 \mathrm{~cm})$ incision was made just to the side of the ventral axis, and the V9 tag was implanted into the abdominal cavity (Fig. 3). An absorbable vicryl suture (Ethicon) was used to evenly place 2 stiches along the incision. Surgery time was typically $<5$ min, after which the fish was turned upright and allowed to immediately swim away. vided into non-spawning (2 April to 12 November) and spawning (13 November to 1 April) time periods based on post hoc movement analysis. The spawning season was defined as starting 1 wk prior to the first detection of a tagged fish at Lang Bank and ending 1 wk after the last detection at Lang Bank. Daily activity patterns during non-spawning months were calculated by averaging the proportion of daily movements between stations that each fish made by hour.

Hourly mean positions were calculated for each fish following the weighted arithmetic mean formula described by Simpfendorfer et al. (2002). Hourly mean positions were used to calculate the center of activity (COA) and to generate the home range estimates for each fish as described below (Udyawer et al. 2018). The COA was calculated by weighting the hourly mean positions by the number of hours at a position divided by the total number of hours detected. The maximum linear distance moved during the non-spawning season from the COA was calculated. In addition to the COA, a home station (station with maximum detections) was identified, and the 


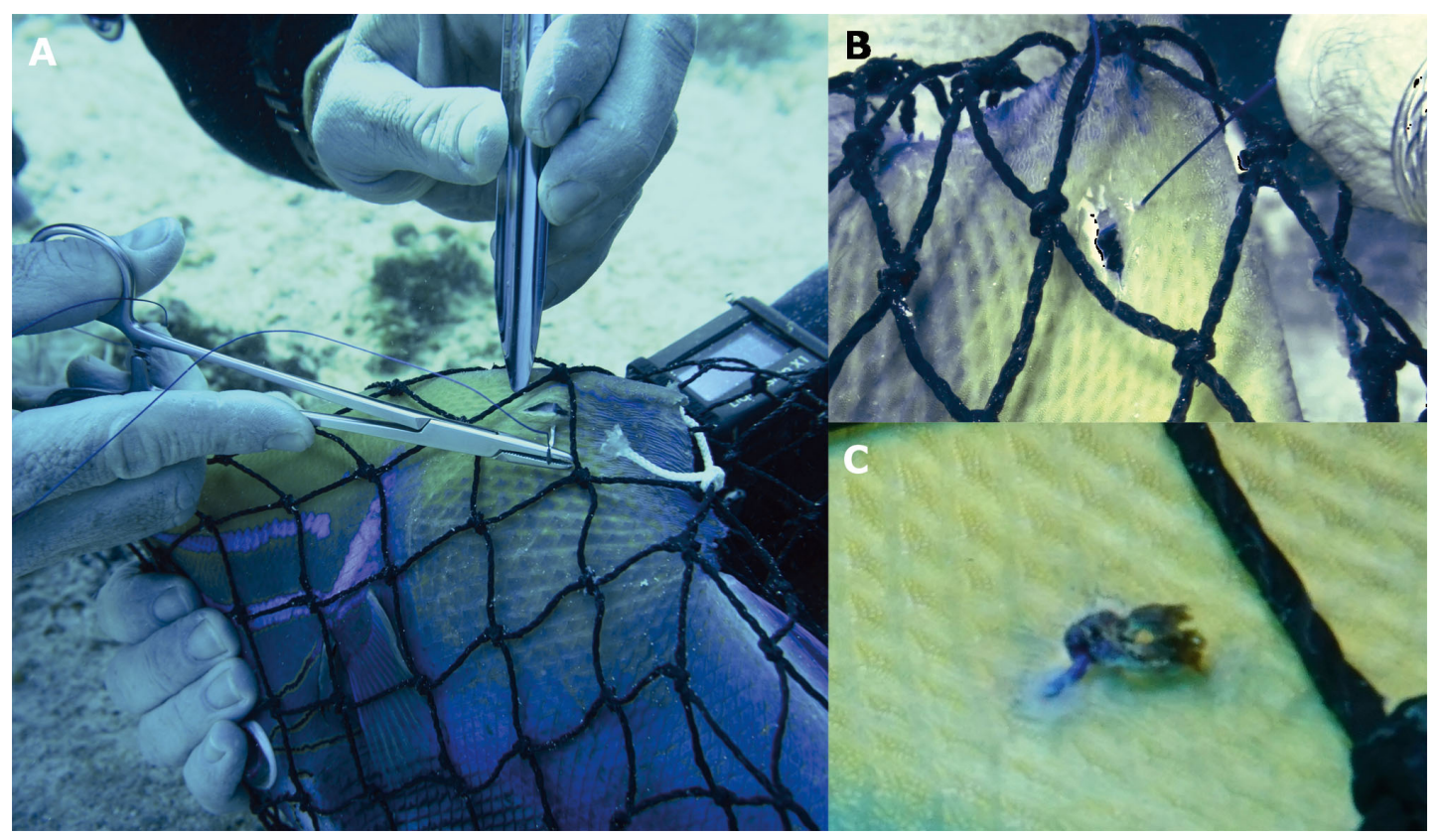

Fig. 3. Underwater surgery methods used for implanting transmitters. (A) Fish were carefully held upside down in a partially immobilized state within a large mesh net. (B) A small $<2 \mathrm{~cm}$ incision was made on the side of the ventral axis allowing for the transmitter to be placed in the abdominal cavity. Incisions were closed with an absorbable vicryl suture using 2 stitches tied with an instrument surgeon knot. (C) Within 1 mo, one wound was found to have healed and the suture material had begun to dissolve

percentage of total detections at the home station was calculated. Home range estimates during the non-spawning season were made for fish that were detected at a minimum of 5 locations. Minimum convex polygon (MCP) and kernel density estimation of utilization distributions (KUD) were computed with the 'adehabitatHR' package in $\mathrm{R}$ (Calenge 2006). We removed $5 \%$ of the hourly locations furthest from the centroid to calculate $95 \%$ MCPs that were used as general estimations of normal home range. Estimates of core use (50\% KUD) and overall use (95\% KUD) were made with the bandwidth parameter set to $201 \mathrm{~m}$, which was the distance of the $10 \%$ detection rate estimated from range tests performed within the array and likely a conservative estimate (Udyawer et al. 2018). Differences in array fidelity, the percent of detections at a home station, and home range size between fish tagged in the northwest region versus the northeast region were tested with a MannWhitney-Wilcoxon $U$-test. Differences in migration timing were tested with a Student's $t$-test. Swimming speed over ground during migrations was calculated by dividing the linear distance between the last station detected within BIRNM and the first station detected at Lang Bank by the timespan between detections. Mean values throughout are presented with \pm standard error (SE).

\section{RESULTS}

\subsection{Range test}

Detection probabilities varied amongst receivers; for half of the stations, no detections were observed when the transmitters were $150 \mathrm{~m}$ away from the station, while at 1 station there was a $6 \%$ detection rate at $328 \mathrm{~m}$ (Fig. 2). Modeled detection probabilities suggested a $50 \%$ detection rate at a distance of $107 \mathrm{~m}, 25 \%$ at $154 \mathrm{~m}$, and $10 \%$ at $201 \mathrm{~m}$ (Fig. 2). There was considerable variance associated with model predictions.

\subsection{Home range}

In total, 60 queen triggerfish were acoustically tagged in $2015(\mathrm{n}=26)$ and $2016(\mathrm{n}=34)$. Sizes ranged from 25.5 to $38.0 \mathrm{~cm}$ FL (mean: $32.4 \pm 0.4 \mathrm{~cm}$ ). Two tagged fish were never detected within the BIRNM array, and 3 fish were tracked for less than $60 \mathrm{~d}$. These 5 fish were removed from further analyses. The average number of days between the first and last detection for the 55 fish used for this study was $434.6 \pm 27.3 \mathrm{~d}$ (Table 1). Twenty-one fish were tagged in the northwest region, and 34 were tagged in the northeast 


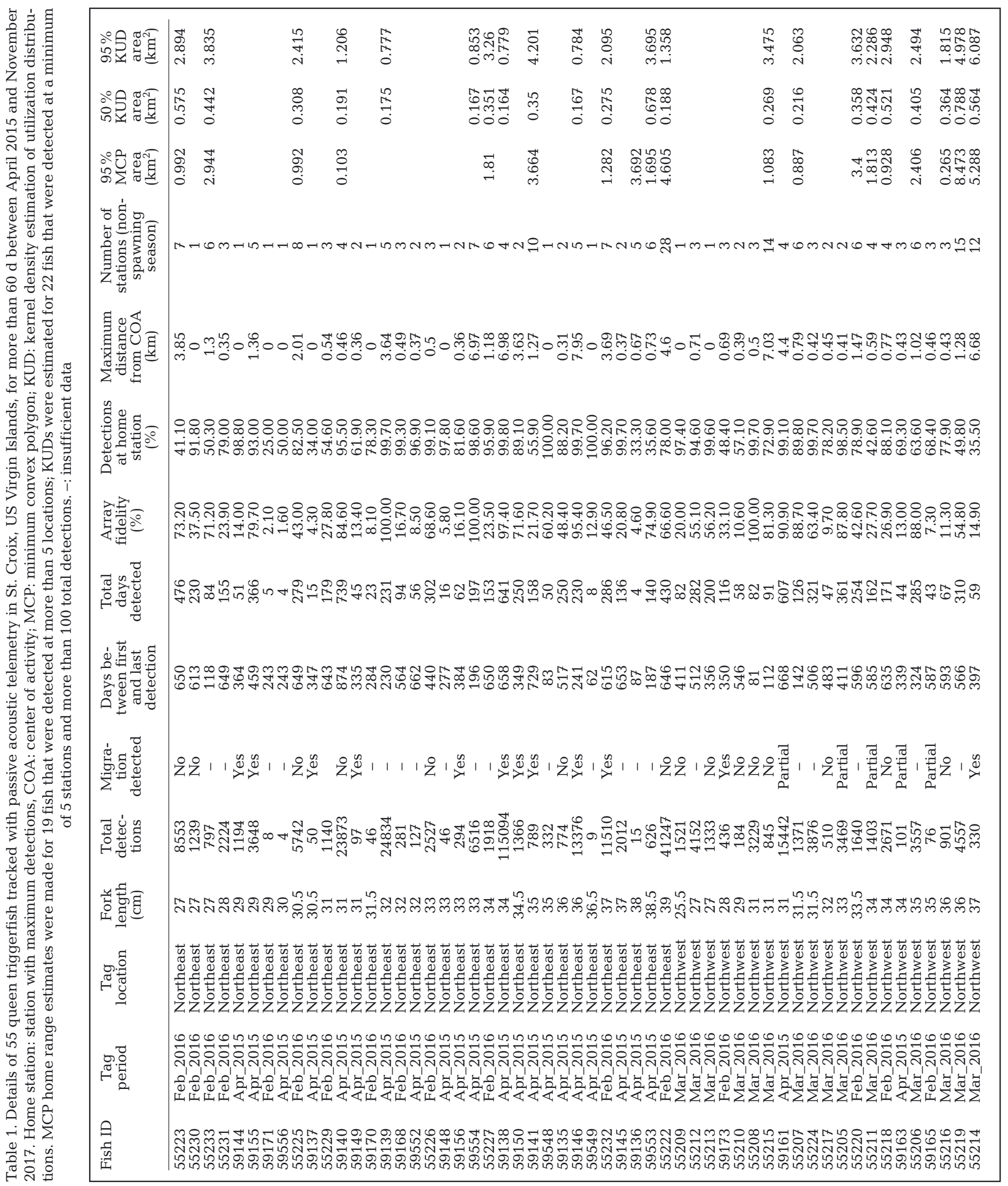


region of BIRNM. A total of 32 fish were detected for longer than $1 \mathrm{yr}$. The average array fidelity within BIRNM was $44.1 \pm 4.4 \%$ and was not significantly different between fish tagged in the northwest $(46.4 \%)$ and northeast $(43.4 \%)$ locations $(U=324, \mathrm{p}=0.57$; Table 1). Queen triggerfish displayed strong site fidelity, and for most individuals, a majority of detections came from a single station. The average percentage of detections at a home station was $77.9 \pm 3.1 \%$, and 21 fish had $>95 \%$ of their detections recorded at a single station (Table 1). Similar to array fidelity, there was no difference in the percentage of detections at a home station between fish tagged in the northwest or northeast locations $(U=401, \mathrm{p}=0.45)$. Not only did the fish spend a majority of their time near a single station, but during non-spawning months (April 2 to November 12), they did not travel far (Fig. 4). The average maximum distance traveled from their COA was $1.5 \pm 0.3 \mathrm{~km}$, and $79 \%$ of fish traveled less than $2 \mathrm{~km}$. Movements between stations largely (87\%) took place between 06:00 and 18:00 h (Fig. 5).

MCP (95\%) home range estimates were made for 19 fish that were detected at more than 5 locations, after outlier locations were removed, during non-

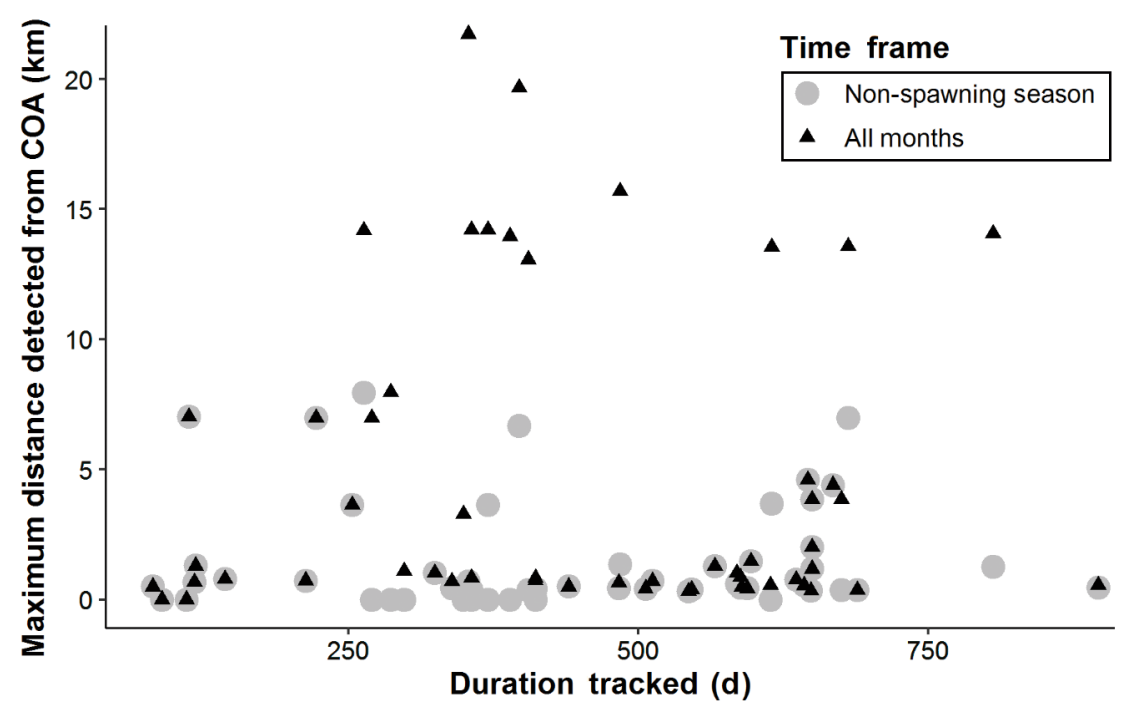

Fig. 4. Maximum linear distance $(\mathrm{km})$ that queen triggerfish $(\mathrm{n}=55)$ moved during the non-spawning season (grey circles) and all months (black triangles) from their center of activity (COA) compared to the number of days they were tracked

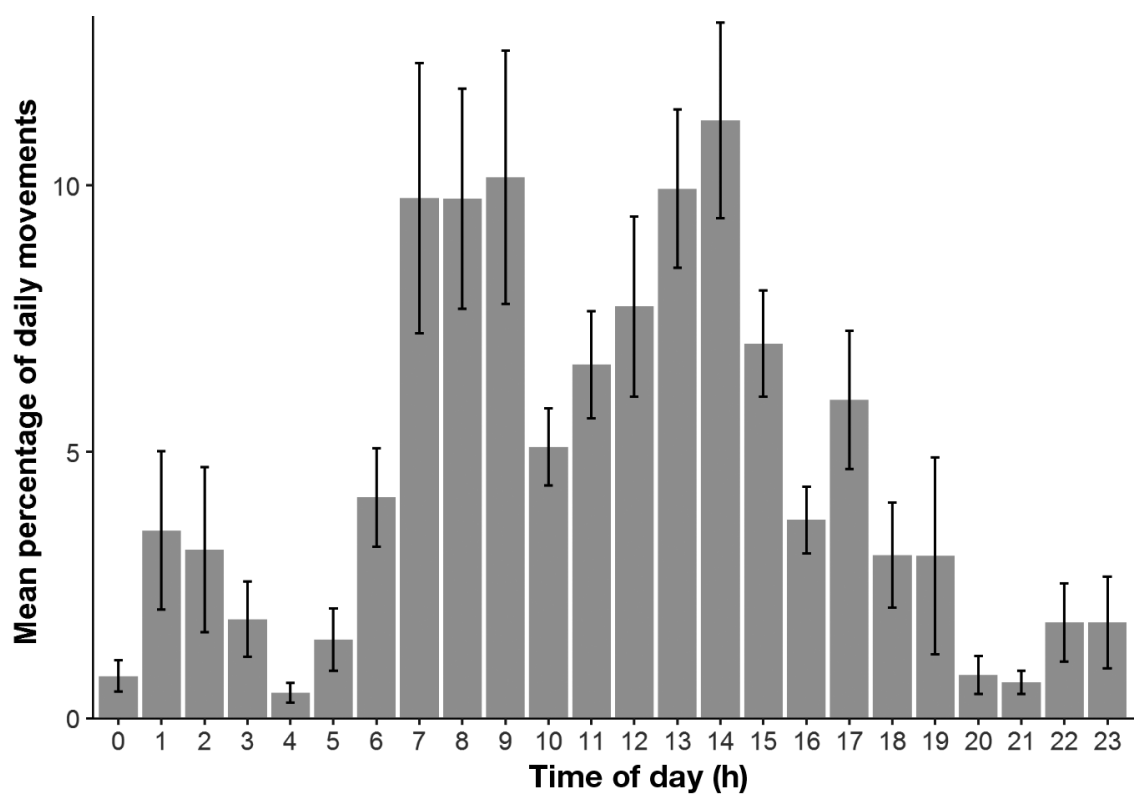

Fig. 5. Daily activity for queen triggerfish $(n=55)$ as measured by the mean percentage of movements by hour. Error bars $=\mathrm{SE}$ 
spawning months (Table 1). The average 95\% MCP was $2.44 \pm 0.30 \mathrm{~km}^{2}$. Home range estimates using $50 \%$ and $95 \%$ KUDs were made for 22 fish that were detected at a minimum of 5 locations and more than 100 total detections, and the average $50 \%$ and $95 \%$ KUDs were $0.36 \pm 0.02$ and $2.63 \pm 0.19 \mathrm{~km}^{2}$, respectively (Table 1). There was no significant difference in home range estimates (MCP, $50 \%$ KUD, and 95\% KUD) between fish tagged in the northwest location versus those tagged in the northeast location $(U=70$, 30 , and $35, \mathrm{p}=0.53,0.06$, and 0.12).

\subsection{Migration}

Several queen triggerfish had reduced site fidelity during the late fall and winter, when they were detected at Lang Bank (Fig. 6). A total of 38 migrations to Lang Bank were observed for 12 individual fish during the winters of 2015/16 and 2016/17. Ten of these individuals were tagged in the northeast region of BIRNM, and 2 were tagged in the northwest region. The earliest detection of a queen triggerfish at Lang Bank was November 19 and the latest

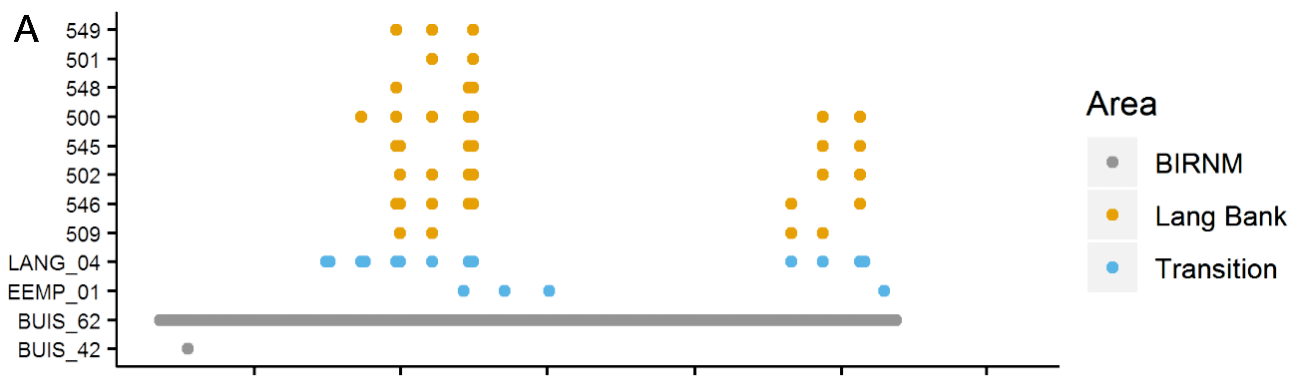

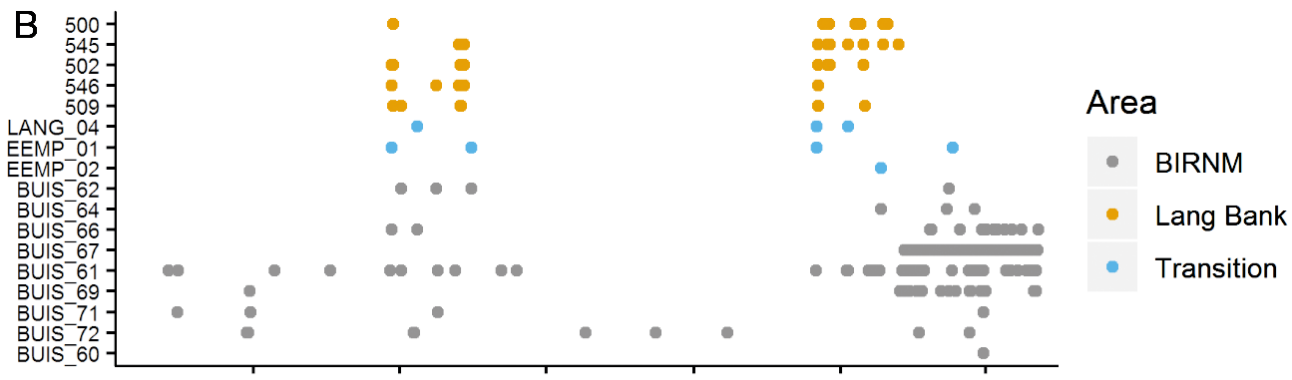

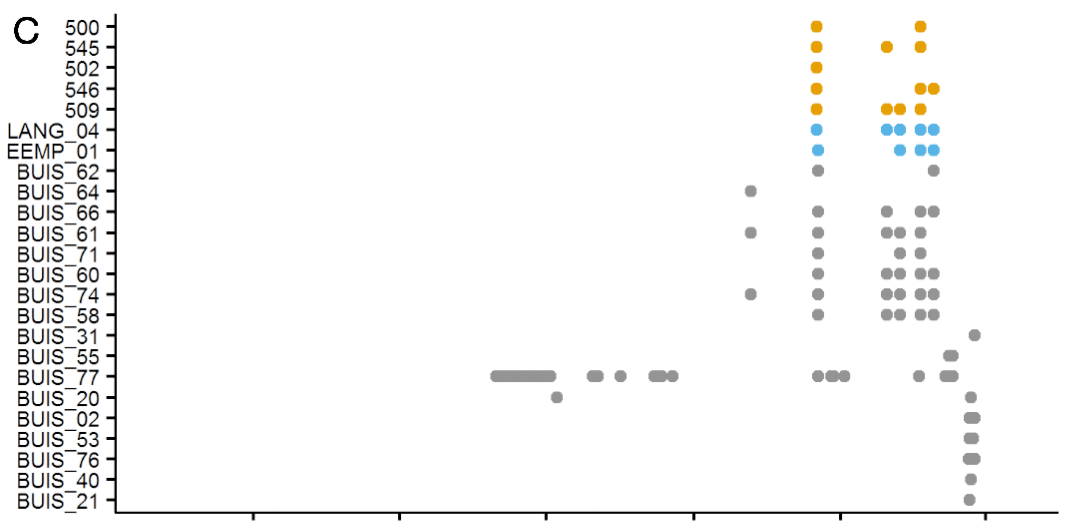

D

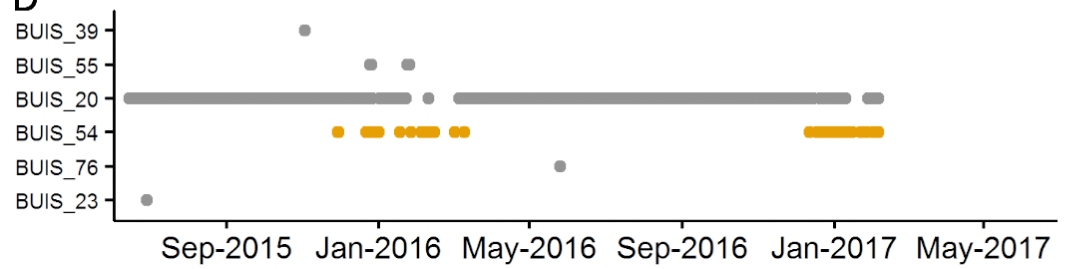

Fig. 6. Daily station locations of 4 queen triggerfish for $2 \mathrm{yr}$ (June 15, 2015 - June 15, 2017) with stations ordered from west on bottom to east on top and color coded by area. Transition stations (in blue) are those outside of Buck Island Reef National Monument (BIRNM) along the northeastern reef edge of St. Croix. (A) Fish 59138 was tagged in the northeast region and had $99.8 \%$ of nonspawning season detections at its home station (BUIS_62). (B) Fish 59141 was also tagged in the northeast region, but it had a much larger home range (9 stations). (C) Fish 55214 was tagged in the northwest region, but migrated to Lang Bank through the northeast region and then followed the same pathway as other fish that were tagged in the northeast. (D) Fish 59161 was tagged in the northwest region and had very high site fidelity during most of the year, but during spawning months it visited Stn BUIS_54, a possible nesting site 
detection was March 25. In 2015/16, the greatest number of detections at Lang Bank occurred during 3 full moons in late December, late January, and late February. Detections during November and March were limited to 2 fish with only 16 total detections. In 2016/2017, the greatest number of detections at Lang Bank was during the full moon in mid-December, mid-January, and mid-February. Similar to 2015/16, detections during November and March were also limited to 2 fish with only 11 detections. We recorded 1 fish making 4 migrations to Lang Bank, but the mode for all fish was 3 migrations. Of the fish that made migrations to Lang Bank, $60 \%$ were detected along the northern reef edge after leaving BIRNM and $42 \%$ were detected along this same path on their return to BIRNM (Fig. 7). Lang Bank Stn 500, located in $32 \mathrm{~m}$ depth just off the reef ridge in an area of colonized reef pavement near the center of the MPA, was the center of spawning activity for queen triggerfish (R. Nemeth \& D. Bryan unpubl. data). The average linear distance between COAs in BIRNM and Stn 500 in Lang Bank was $15.09 \pm 0.64$ km (Fig. 4). The time between the last detection in BIRNM and first detection at Lang Bank varied, but $42 \%$ of migrations to the spawning site and $36 \%$ of homeward migrations took place in less than $12 \mathrm{~h}$. The average time between BIRNM and Lang Bank for this subset of fish was $6.74 \pm 0.40 \mathrm{~h}$ and required a swimming speed of $1.96 \pm 0.08 \mathrm{~km} \mathrm{~h}^{-1}$. The average time for these swims was not significantly different from homeward trips, which took $6.34 \pm 0.34 \mathrm{~h}$, with an average swimming speed of $2.05 \pm 0.09 \mathrm{~km} \mathrm{~h}^{-1}$. Both fish that migrated from the northwest region of BIRNM to Lang Bank were also detected in the northeast region of the array during their migration to and from Lang Bank (Figs. 6 \& 7). Fish 55214 was detected at the same stations during repeated outward and homeward migrations at the same time of day $( \pm 2 \mathrm{~h})$.

On average, fish were first detected at Lang Bank $1.3 \pm 0.5 \mathrm{~d}$ after the full moon and were last detected $5.3 \pm 0.4 \mathrm{~d}$ after the full moon (Fig. 8). The arrival pathway for most fish was past Stns 509 and 546 at the northern end of Lang Bank (Fig. 7). Fish that were recorded during multiple migrations and that were first detected at these stations showed a consis-

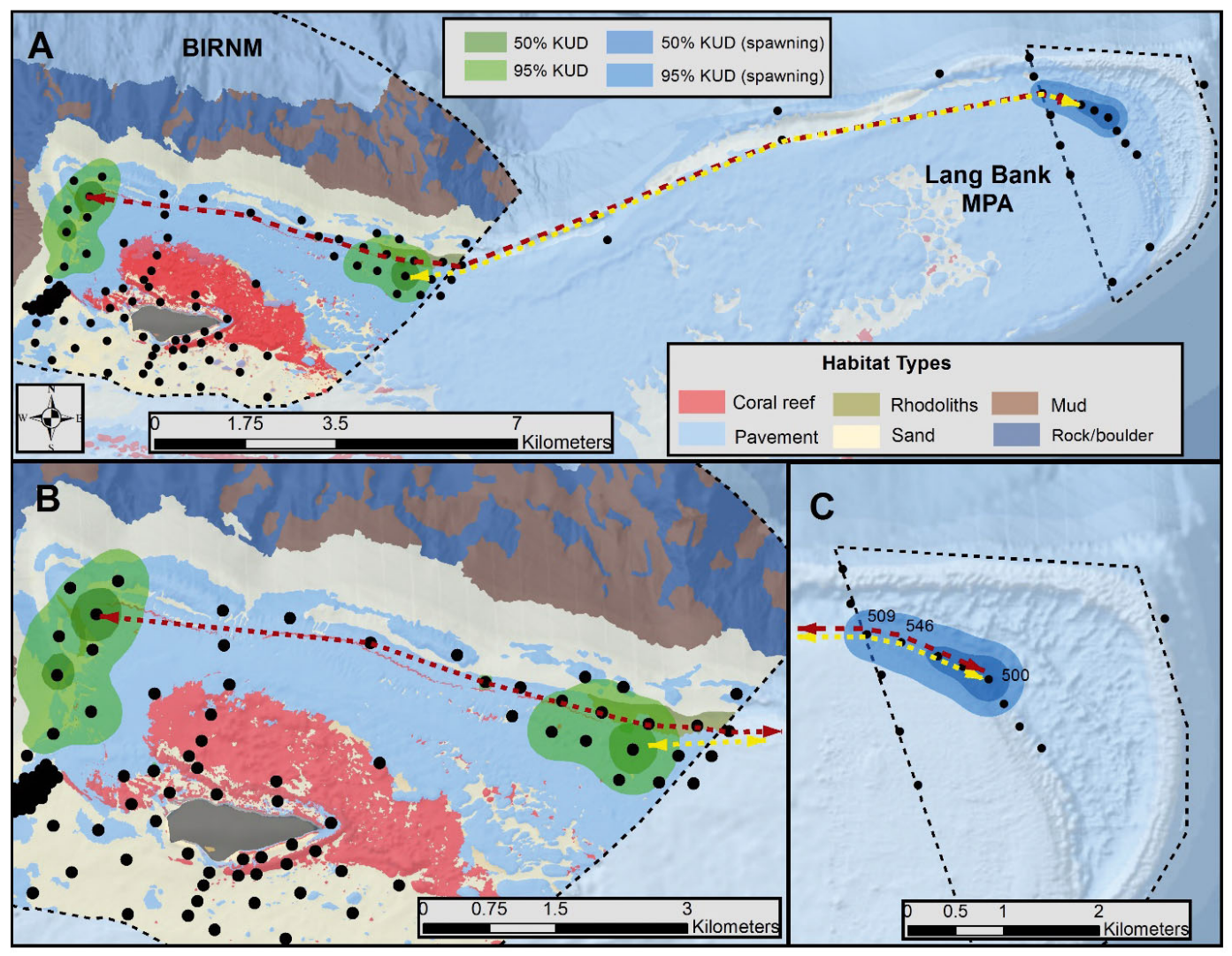

Fig. 7. (A,B) Resident home ranges (50 and 95\% kernel density estimation of utilization distributions, KUDs) of Fish 55214 in northwest Buck Island Reef National Monument (BIRNM) and Fish 59141 in northeast BIRNM. The migration and return pathway for Fish 55214 is shown with a red dashed line and Fish 59141 with a yellow dashed line. (C) Combined spawning areas (50 and $95 \%$ KUDs) for Fish 55214 and 59141 and the pathway used by both fish when entering and exiting the spawning area. MPA: marine protected area 
tent preference for the timing of their arrival at Lang Bank. A majority of fish first arrived at Lang Bank between 13:00 and 16:00 $\mathrm{h}$ in the afternoon. The precise timing of departure was more difficult to determine, as the last station at which fish were detected was often neither Stn 509 nor 546. For those fish that were last detected at these stations, the majority left Lang Bank between 08:00 and 10:00 $\mathrm{h}$ in the morning. Individual fish that were tracked at least once to Lang Bank made an average of $2.5 \pm 0.21$ trips per season. During their time at Lang Bank, fish had an average residence time of $4.0 \pm 0.7 \mathrm{~d}$, and individuals were detected on average at $3.0 \pm 0.4$ stations.

Two fish (59138 and 59141) that were tagged in the northeast region and tracked for 658 and $729 \mathrm{~d}$, respectively, returned to Lang Bank in consecutive years (Fig. 6). Fish 59138 had extremely high site fidelity in BIRNM, with $99.8 \%$ of resident detections occurring at a single station. Fish 59141 was detected at a greater number of stations during the nonspawning season in BIRNM, but similar to 59138, returned to the same area within BIRNM after migrating to Lang Bank. At Lank Bank, Fish 59141 entered the area near Stn 509 and then swam towards Stn 500, where it typically spent most of its time. Most queen triggerfish followed a similar spatial pattern during their migration to Lang Bank and their time spent at Lang Bank (R. Nemeth \& D. Bryan unpubl. data).

Despite the detection of several spawning migrations to Lang Bank from both the northeast and northwest region of BIRNM, a majority (79\%) of queen triggerfish were never detected at Lang Bank. In the northwest region of BIRNM, 5 fish were exclusively detected at Stn BUIS_54, located on the northwestern corner of the array in $28 \mathrm{~m}$ depth, during the same time of the year when fish were detected at Lang Bank. The earliest detection was on November 29 and the latest detection was on March 26. Nineteen trips to Stn BUIS_54 were detected for these 5 fish during this time period. On average, these fish were first detected at this station $0.4 \pm$ $1.0 \mathrm{~d}$ prior to the full moon and were last detected $4.3 \pm 0.9 \mathrm{~d}$ after (Fig. 6). The average duration of a trip to Stn BUIS_54 was $4.7 \pm 1.4 \mathrm{~d}$. The average number of detections during these trips was low $(7 \pm 2.5)$, and 7 trips con- sisted of only a single detection. This indicates that some fish passed Stn BUIS_54 and likely spawned nearby, but in an area that was not within our detection range. The fish made an average of 2.5 trips $\mathrm{yr}^{-1}$ to Stn BUIS_54. There was no significant difference in the average time of arrival or departure in relation to the full moon at Stn BUIS_54 when compared to arrival and departure times at Lang Bank $(t=1.47$, $\mathrm{p}=0.15$ and $t=0.94, \mathrm{p}=0.35$, respectively). Stn BUIS_54 was very close to the home ranges of these fish, and the average linear distance from their COAs to Stn BUIS_54 was only $0.7 \pm 0.03 \mathrm{~km}$ (Fig. 9). Seven other fish that were tagged in the northwest region were also detected at Stn BUIS_54 during the spawning season, but they had home ranges that included this station, so it was not possible to categorize those detections explicitly as an indication of spawning movements.

\subsection{Tag recovery}

Two fish that had been tagged in February of 2016 were reported captured by a local fisherman in March and April of 2018 at Lang Bank with fish traps. One fish (55227) had been tracked for $650 \mathrm{~d}$ in the northeastern portion of BIRNM and had never been detected on Lang Bank. The other fish (59167), was 1 of 2 that had never been detected within the BIRNM
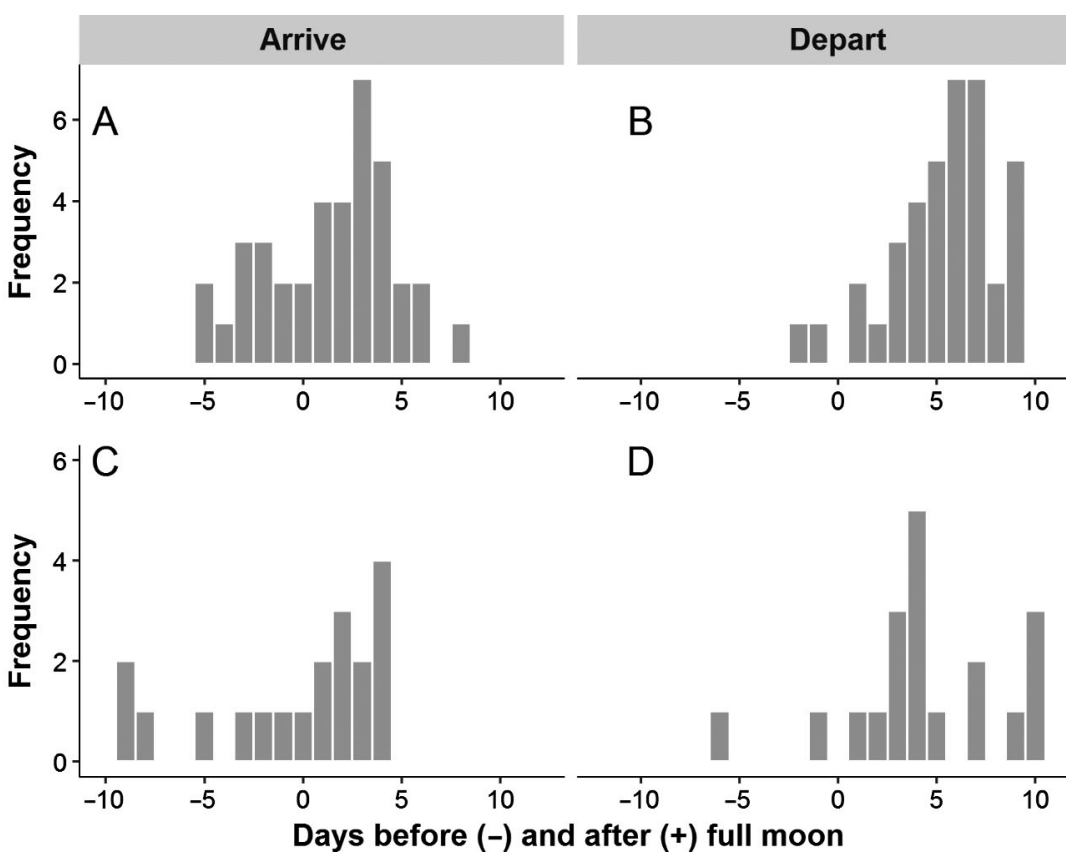

Fig. 8. Frequency of the time of arrival (first detection) and departure (last detection) of queen triggerfish compared to the full moon, during their migrations to $(\mathrm{A}, \mathrm{B})$ Lang Bank and $(\mathrm{C}, \mathrm{D})$ Stn BUIS_54 


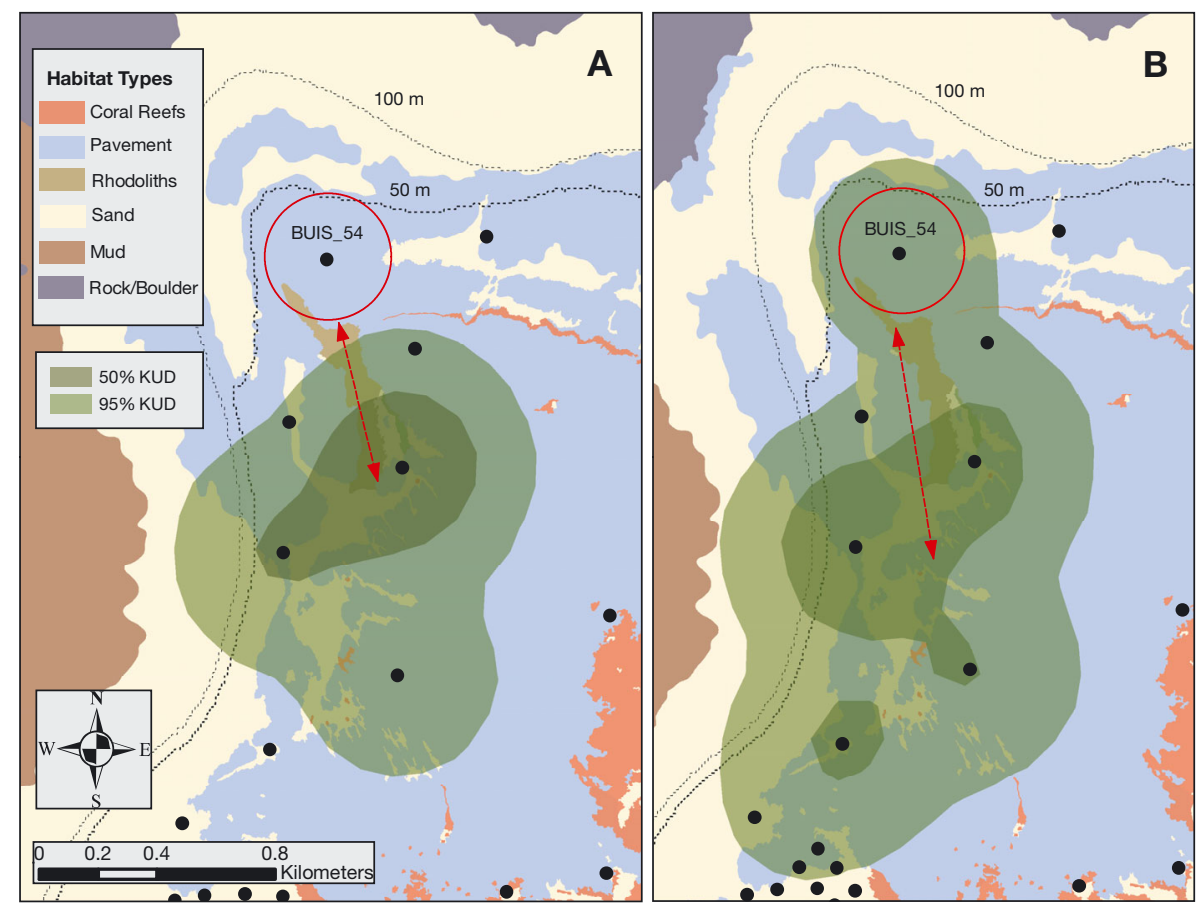

Fig. 9. Home range estimates (50 and $95 \%$ kernel density estimation of utilization distributions, KUDs) for queen triggerfish (A) 55211 and (B) 55219 during the non-spawning seasons from April 2016 until November 2017 that were tagged in the northwest region of BIRNM. Fish 55211 was only detected at Stn BUIS_54 (circled in solid red; 201 m radius represents the predicted distance for a $10 \%$ detection probability) during the spawning season. Fish 55219 was also detected at Stn BUIS_54 during the spawning season, but the station was within its overall use area (95\% KUD). Red dashed line indicates pathway from center of activity to potential spawning location. Dark dashed lines represent 50 and $100 \mathrm{~m}$ depth contours

or Lang Bank acoustic arrays. The capture of these fish represents a minimum 2 yr fishing mortality rate of $3.3 \%$ for all tagged fish $(\mathrm{n}=60)$ and a much higher $14.3 \%$ fishing mortality rate for queen triggerfish known to have migrated to Lang Bank during the study period ( $\mathrm{n}=14$ [12 tracked plus 2 captured]).

\section{DISCUSSION}

Queen triggerfish displayed persistent and high site fidelity along with relatively small home ranges during non-spawning months. For part of the tagged population, this movement pattern was interrupted briefly by repeated spawning migrations from late fall through the winter to a transient nesting site. High site fidelity is common to many species of reef fish (Popple \& Hunte 2005, Meyer et al. 2010, Topping \& Szedlmayer 2011) and has also been observed in gray triggerfish (Ingram \& Patterson 2001, Herbig \& Szedlmayer 2016). Home range sizes vary among reef fish (Green et al. 2015), but the 95\% KUD $\left(0.77-6.09 \mathrm{~km}^{2}\right)$ of queen triggerfish was comparable to that of other similarly sized benthic carnivores (March et al. 2010, Farmer \& Ault 2011, Currey et al.
2014, Feeley et al. 2018). High food abundance and the availability of shelter has been hypothesized as the reason for high site fidelity and small resident home ranges for reef fish (Kramer \& Chapman 1999, Grüss et al. 2011a, Green et al. 2015). The interface between reef pavement and rhodoliths, along the edge of the reefs near our tagging stations, may provide ideal habitat for queen triggerfish. After the dieoff of long-spined sea urchins Diadema antillarum, which were once a main food item, queen triggerfish have been reported to feed on a range of organisms including crabs, chitons, polychaetes, and other echinoids (Randall 1967, Reinthal et al. 1984, Turingan et al. 1995). These prey items are likely abundant in the diverse and productive rhodolith beds (James 2000, Berlandi et al. 2012), and we observed queen triggerfish tipping over loose rhodoliths, presumably looking for food. Almost $90 \%$ of the movements between stations took place between 06:00 and 18:00 h, suggesting that they are diurnal foragers (Turingan et al. 1995). Queen triggerfish are also reported to prey upon Caribbean spiny lobsters Panulirus argus (Weiss et al. 2006), which we observed in the small ledges and crevices in the adjacent reef pavement. These small spaces may also provide nighttime shelters 
for queen triggerfish. Although it is possible that the sharp decrease in movement among stations at night is a result of fish moving outside of the range of acoustic array, we did not observe any consistent movements either away from or towards their COA during crepuscular hours. The close proximity of foraging grounds and sheltering areas likely explains the limited movement patterns of the fish during non-spawning months.

The queen triggerfish within BIRNM appeared to exhibit a partial migration strategy, in which both resident and migratory contingents exist within the population (Kerr \& Secor 2012). In the migratory contingent, fish with typical high site fidelity migrated to Lang Bank several times from November until March around the full moon. In situ observation of queen triggerfish nests at Lang Bank (R. Nemeth unpubl. data) suggests that these movements represent spawning migrations. Furthermore, an examination of queen triggerfish gonads by Hernández et al. (2019) in St. Croix indicated a potential spawning season from November to August, with the highest proportion of spawning-capable females in February.

Hernández et al. (2019) also found that spawning activity was associated with the full moon, but their sampling design did not allow them to determine the specific timing. The correlation of migration with the lunar cycle, and in particular, with the full moon, is common among a large number of Caribbean reef fishes (Colin 1992, Starr et al. 2007, Heyman \& Kjerfve 2008, Schärer et al. 2012, Feeley et al. 2018). In the USVI, cubera snapper Lutjanus cyanopterus, dog snapper L. jocu, Nassau grouper Epinephelus striatus, red hind E. guttatus, and yellowfin grouper $M y c-$ teroperca venenosa have all exhibited peak spawning activity directly following a full moon (Kadison et al. 2006, Nemeth et al. 2007, Rowell et al. 2015, Biggs \& Nemeth 2016). Interestingly, all of the spawning migrations reported above have been for fish with a broadcast spawning reproduction strategy. In contrast, Balistidae spawn in pairs and deposit demersal eggs that are guarded by either a single or both parents and typically hatch during the first evening or within 24 h (Fricke 1980, Lobel \& Johannes 1980, Kawase 2002, Simmons \& Szedlmayer 2012, Clark et al. 2015). Despite this difference in reproductive strategy, queen triggerfish also time their spawning migrations with the full moon. Similar to other reef fishes, they make multiple spawning migrations each year (Kobara et al. 2013). We recorded 1 individual making 4 migrations to Lang Bank, but the mode for all fish was 3 migrations per year. This is similar to the estimate by Hernández et al. (2019) that female queen triggerfish could spawn 4-5 times a year. In both the 2015/16 and 2016/17 spawning seasons, December, January, and February appeared to be the most active months for our tagged fish at Lang Bank, with few detections in November and March. The monthly and lunar timing of peak migration and spawning of queen triggerfish matches very closely with the red hind (E. guttatus) and seem to aggregate adjacent to red hind spawning sites, but in deeper sand and rubble habitats suitable for nest building (Nemeth et al. 2007, Kadison et al. 2009).

Migrating queen triggerfish appear to have a distinct pathway along the northern edge of the reef, and the majority of fish arrive at Lang Bank in the same area at the same time during each migration. Their migratory swimming speeds $\left(1.98 \mathrm{~km} \mathrm{~h}^{-1}\right)$ are similar to measurements made from acoustic telemetry for other reef fish during migrations. These include coral trout Plectropomus leopardus $(0.66 \mathrm{~km}$ $\mathrm{h}^{-1}$, Zeller 1998), mutton snapper L. analis $(2.2 \mathrm{~km}$ $\mathrm{h}^{-1}$, Feeley et al. 2018), Nassau grouper (1.69-1.96 km $\mathrm{h}^{-1}$, Starr et al. 2007, Rowell et al. 2015, Stump et al. 2017), and yellowfin grouper $\left(2.03 \mathrm{~km} \mathrm{~h}^{-1}\right.$, Rowell et al. 2015). The 2 fish that migrated from the northwest region of BIRNM also had a very distinct pathway through BIRNM in which certain stations were passed at the same time of day, within a few hours, on repeated migrations. Distinct migratory corridors have been noted for other reef species (Mazeroll \& Montgomery 1998, Rhodes et al. 2012, Biggs \& Nemeth 2016). The knowledge of predictable movement patterns can be exploited by fishers to increase their efficiency (Claro et al. 2001, Sadovy de Mitcheson \& Erisman 2012). However, this knowledge can also be beneficial if incorporated into spatial management (Erisman et al. 2017).

A number of individuals that were consistently tracked were not detected at Lang Bank during the spawning season. Three possible explanations are: (1) not all tagged fish were sexually mature; (2) not all tagged fish that migrated to Lang Bank were detected; and (3) Lang Bank is not the only nesting site for queen triggerfish that reside in BIRNM. All of our fish were above the size at $50 \%$ sexual maturity reported by Hernández et al. (2019) in St. Croix. However, those authors found that $100 \%$ sexual maturity for females did not occur until 35.1-37.5 cm FL. This was close to the size of our largest fish $(38.0 \mathrm{~cm})$, and thus it is probable that some of our tagged fish were immature females. The presence of immature females in our study would help explain the lack of migrations for some individuals. We also know that at least 2 tagged fish, which were caught 
by a local fisherman, had made the migration to Lang Bank but were not detected by our acoustic array. The spatial extent of the nesting grounds at Lang Bank is unknown, and given the limited number of receivers at Lang Bank and their relatively small detection range, it is highly likely that other fish also had made the migration but were undetected. It is also unlikely that Lang Bank is the only queen triggerfish nesting site on the St. Croix shelf. Within BIRNM, we found 5 fish that were only detected at a station (BUIS_54) near their COAs during the late fall and early winter. The timing of detections and the temporal movement patterns of these fish were not significantly different from those of fish that underwent spawning migrations to Lang Bank. We believe that the area around this station represents a local nesting site and that the fish that visited this area during the spawning season make up a resident contingent of queen triggerfish that do not migrate outside the BIRNM to spawn. The location of Stn BUIS_54 in the northwest corner of the reef tract is close to a significant depth drop-off that has been considered a possible reef spawning aggregation site for other species (Weber \& Brown 2009, Kobara et al. 2013). Furthermore, the positions of the other receivers and the frequency of detections for some fish make it unlikely that queen triggerfish were using this area as a pathway for a longer migration. In addition to the fish that were only detected at Stn BUIS_54 during the spawning season, 7 other fish were also detected at the station during the spawning season; however, since the area was part of their home range, it was not possible to definitively classify those detections as spawning related. Interestingly, no fish that were tagged in the northeast region of BIRNM migrated to the west through our array during the spawning season. The distance from the northeast region to Stn BUIS_54 is roughly $6 \mathrm{~km}$, which is half the distance to Lang Bank. Instead of migrating west, it is possible that there is also a local nesting site in the northwest region of BIRNM that was either not covered by our receivers or was near a station that was encompassed by their home ranges and could not be separated from daily detections.

An important aspect of determining residency and home range sizes is the accuracy of an acoustic telemetry array. Range tests revealed highly variable detection probabilities across 6 receivers in our array during typical weather conditions in St. Croix. These results are similar to other acoustic studies on tropical reefs in the USVI where environmental factors such as depth, current, bottom topography, and temperature all influence the detection of acoustic signals
(Selby et al. 2016, Jossart et al. 2017). The predicted distance $(107 \mathrm{~m})$ at a $50 \%$ detection probability is similar to extensive work done by Selby et al. (2016) within the same BIRNM array ( $58 \%$ detection probability at $100 \mathrm{~m}$ ) and that of Kendall et al. (2016) in St. John, USVI ( $50 \%$ detection probability at $125 \mathrm{~m}$ ). Detection ranges can also have diurnal and seasonal variations which we were not able to incorporate into our study due to a lack of standardized controls (Payne et al. 2010, Mathies et al. 2014). Variation in detection ranges has the potential to introduce a bias into the analysis or cause the misinterpretation of results (Payne et al. 2010). The increase of fish movements during daylight hours, which we have associated with foraging behavior, has the potential to be an artifact of differences in detection rates. However, Selby et al. (2016) looked at temporal changes in detection rate within the same array in BIRNM and found mixed results; at one station, detections decreased at night, at another they increased, and at 2 stations they were the same. They concluded that the temporal variability in detection range may not be uniform across BIRNM. Thus, we believe that on average, detection probabilities across the BIRNM array are similar during the day and night and that the increase in movement during the day was genuine.

Fisheries management strives for sustainable harvest of fish stocks through size, effort, and catch limits while simultaneously protecting vulnerable life stages and essential habitats (Botsford et al. 1997). In regions where harvest control rules are weak to non-existent, additional protection through no-take marine reserves can be beneficial (Lauck et al. 1998, Hilborn et al. 2004, Ault et al. 2013). However, for marine reserves to work, closed areas must match with spatial distributions and movement patterns of fish (Kramer \& Chapman 1999, Cornejo-Donoso et al. 2017, Weeks et al. 2017). The discovery of both a resident and migratory contingent of queen triggerfish has interesting implications for their management throughout their range and is very beneficial for the population around St. Croix. Partial migratory populations have been described for a number of fish (Chapman et al. 2012a,b), and as more studies take advantage of new technologies to conduct long-term monitoring of fish, the number of species reported to use this tactic may increase (Papastamatiou et al. 2013, Espinoza et al. 2016, Reid et al. 2018). In St. Croix, the large BIRNM no-take reserve $\left(20 \mathrm{~km}^{2}\right)$ and the Lang Bank seasonal closed area together provide a comprehensive level of protection potential for queen triggerfish if there is adequate enforcement of spatial regulations and compliance by fishers (Ken- 
dall et al. 2017). Migratory queen triggerfish with home ranges within BIRNM are potentially only exposed to fishing pressure along their migration pathway to Lang Bank and in the spawning months prior to and after the December 1 to February 28 closure. The migration between BIRNM and Lang Bank appears to be direct for a majority of individuals and constitutes a minimal amount of time exposed to fishing mortality, since most fish arrive at Lang Bank within $6 \mathrm{~h}$. However, migratory queen triggerfish may make multiple migrations each year, and fish traps, which are commonly used to capture queen triggerfish, are often placed along this pathway. During our study period, 1 out of 12 fish that migrated to Lang Bank did not return to its COA, which could indicate fishing mortality. In addition, 2 of our original 60 tagged fish were caught by a local fisherman in Lang Bank during spawning months but after the seasonal closure was lifted. The capture of these fish highlights the potential risks encountered by queen triggerfish that migrate outside of BIRNM to a known spawning site. Combined, the capture of these 2 fish and the potential capture of the tracked fish that was not detected after leaving Lang Bank represents a $21 \%$ fishing mortality rate over $2 \mathrm{yr}$ for the fish known to have left BIRNM ( $=14)$, but only a $5 \%$ fishing mortality rate for the entire tagged BIRNM population.

In contrast to the migratory spawners, a majority of the queen triggerfish that we tagged remained within BIRNM during the duration of the study. Some of these fish may have been immature, but others likely used local nesting sites to reproduce. Little is known of the pelagic larval phase of queen triggerfish post hatch, but increment analysis of 70 otoliths collected in April from newly settled juveniles in Panama revealed that these fish were between 66 and $86 \mathrm{~d}$ old (Robertson 1988). Recruitment patterns in St. Croix are likely driven by wake flow eddies created as the northward circulation of the Caribbean Sea comes in contact with the island (Chérubin \& Garavelli 2016). The creation of these eddies, which could influence the local retention of recruits, is seasonally variable, and it is unclear how the conditions during the winter months would affect the local retention of queen triggerfish from various spawning sites (Chérubin \& Garavelli 2016). It is possible that the larvae of resident queen triggerfish that spawn in BIRNM settle outside of the reserve boundaries and provide an important source of recruits for the fishery. Thus, the protection of mature fish within BIRNM is key to supporting a sustainable local fishery.
Acknowledgements. National Park Service (NPS) staff Tessa Code and Jeff Gay were a tremendous help with in situ tagging operations and led the colossal task of downloading and maintaining the acoustic array. NPS Inventory and Monitoring staff, including Mikey Kent, Jeff Miller, Lee Richter, and Rob Warra, assisted with tagging and the range testing of receivers. Ian Lundgren was instrumental in acquiring NPS funding (PMIS 141633) for establishing the BIRNM acoustic array. We greatly appreciate local fisherman Tom Daley for reporting the 2 tags that he found. We also thank our partners at the University of Massachusetts, National Marine Fisheries Service's Galveston Laboratory, US Geological Survey, and NOAA National Ocean Services Biogeography Branch for sharing acoustic receivers and data. The installation and maintenance of acoustic receivers on Lang Bank was assisted by University of the Virgin Islands staff and students Chris Biggs, Marcia Taylor, Jonathan Brown, Damon Green, Sarah Heidman, and Elizabeth Kadison. Support for this study was partially provided by the National Oceanic and Atmospheric Administration (MARFIN, project number: NA13NMF4330167) and the Virgin Islands Experimental Program to Stimulate Competitive Research (National Science Foundation, project number: 1355437). This is contribution number 204 to the University of the Virgin Islands Center for Marine and Environmental Studies.

\section{LITERATURE CITED}

Ault JS, Smith SG, Bohnsack JA, Luo J and others (2013) Assessing coral reef fish population and community changes in response to marine reserves in the Dry Tortugas, Florida, USA. Fish Res 144:28-37

*Becker SL, Finn JT, Danylchuk AJ, Pollock CG, Hillis-Starr Z, Lundgren I, Jordaan A (2016) Influence of detection history and analytic tools on quantifying spatial ecology of a predatory fish in a marine protected area. Mar Ecol Prog Ser 562:147-161

Berlandi RM, Figueiredo MAO, Paiva PC (2012) Rhodolith morphology and the diversity of polychaetes off the southeastern Brazilian coast. J Coast Res 28:280-287

Biggs CR, Nemeth RS (2016) Spatial and temporal movement patterns of two snapper species at a multi-species spawning aggregation. Mar Ecol Prog Ser 558:129-142

* Botsford LW, Castilla JC, Peterson CH (1997) The management of fisheries and marine ecosystems. Science 277: 509-515

Botsford LW, Brumbaugh DR, Grimes C, Kellner JB and others (2009) Connectivity, sustainability, and yield: bridging the gap between conventional fisheries management and marine protected areas. Rev Fish Biol Fish 19:69-95

* Bryan DR, Smith SG, Ault JS, Feeley MW, Menza CW (2016) Feasibility of a regionwide probability survey for coral reef fish in Puerto Rico and the US Virgin Islands. Mar Coast Fish 8:135-146

Calenge C (2006) The package adehabitat for the R software: a tool for the analysis of space and habitat use by animals. Ecol Model 197:516-519

Carruthers TR, Punt AE, Walters CJ, MacCall A, McAllister MK, Dick EJ, Cope J (2014) Evaluating methods for setting catch limits in data-limited fisheries. Fish Res 153: $48-68$

* Chapman B, Hulthén K, Brodersen J, Nilsson PA, Skov C, Hansson LA, Brönmark C (2012a) Partial migration in 
fishes: causes and consequences. J Fish Biol 81:456-478

Chapman B, Skov C, Hulthén K, Brodersen J, Nilsson PA, Hansson LA, Brönmark C (2012b) Partial migration in fishes: definitions, methodologies and taxonomic distribution. J Fish Biol 81:479-499

Chérubin LM, Garavelli L (2016) Eastern Caribbean circulation and island mass effect on St. Croix, US Virgin Islands: a mechanism for relatively consistent recruitment patterns. PLOS ONE 11:e0150409

Clark E, Nelson DR, Dreyer R (2015) Nesting sites and behavior of the deep water triggerfish Canthidermis maculata (Balistidae) in the Solomon Islands and Thailand. Aqua Int J Ichthyol 21:1-38

Claro R, Baisre JA, Lindeman KC, Garcia-Arteaga JP (2001) Cuban fisheries: historical trends and current status. In: Claro R, Lindeman KC, Parenti LR (eds) Ecology of the marine fishes of Cuba. Smithsonian Institution Press, Washington, DC, p 194-219

Colin PL (1992) Reproduction of the Nassau grouper, Epinephelus striatus (Pisces: Serranidae) and its relationship to environmental conditions. Environ Biol Fishes 34: 357-377

Cornejo-Donoso J, Einarsson B, Birnir B, Gaines SD (2017) Effects of fish movement assumptions on the design of a marine protected area to protect an overfished stock. PLOS ONE 12:e0186309

Costa BM, Tormey S, Battista TA (2012) Benthic habitats of Buck Island Reef National Monument. Tech Memo NOS NCCOS 142. NOAA, Silver Spring, MD

Crisafulli B, Fairclough D, Keay I, Lewis P and others (2018) Does a spatio-temporal closure to fishing Chrysophrys auratus (Sparidae) spawning aggregations also protect individuals during migration? Can J Fish Aquat Sci, doi:10.1139/cjfas-2017-0449

Crossin GT, Heupel MR, Holbrook CM, Hussey NE and others (2017) Acoustic telemetry and fisheries management. Ecol Appl 27:1031-1049

Currey LM, Heupel MR, Simpfendorfer CA, Williams AJ (2014) Sedentary or mobile? Variability in space and depth use of an exploited coral reef fish. Mar Biol 161: 2155-2166

* Erisman B, Heyman W, Kobara S, Ezer T, Pittman S, Aburto Oropeza O, Nemeth RS (2017) Fish spawning aggregations: where well-placed management actions can yield big benefits for fisheries and conservation. Fish Fish 18:128-144

Espinoza M, Heupel MR, Tobin AJ, Simpfendorfer CA (2016) Evidence of partial migration in a large coastal predator: opportunistic foraging and reproduction as key drivers? PLOS ONE 11:e0147608

Farmer NA, Ault JS (2011) Grouper and snapper movements and habitat use in Dry Tortugas, Florida. Mar Ecol Prog Ser 433:169-184

Farmer NA, Ault JS (2018) Accounting for detection gaps when evaluating reef fish habitat use in an acoustic array. Can J Fish Aquat Sci 75:375-388

Farmer NA, Ault JS, Smith SG, Franklin EC (2013) Methods for assessment of short-term coral reef fish movements within an acoustic array. Mov Ecol 1:7

Feeley MW, Morley D, Acosta A, Barbera P, Hunt J, Switzer $\mathrm{T}$, Burton M (2018) Spawning migration movements of mutton snapper in Tortugas, Florida: spatial dynamics within a marine reserve network. Fish Res 204:209-223

Fricke HW (1980) Mating systems, maternal and biparental care in triggerfish (Balistidae). Ethology 53:105-122
Gaines SD, White C, Carr MH, Palumbi SR (2010) Designing marine reserve networks for both conservation and fisheries management. Proc Natl Acad Sci USA 107: 18286-18293

Garcia-Moliner G, Arnold B (2013) Caribbean blue tang and queen triggerfish assessment. SEDAR 30, NOAA Southeast Data Assessment and Review, North Charleston, SC

*Green AL, Maypa AP, Almany GR, Rhodes KL and others (2015) Larval dispersal and movement patterns of coral reef fishes, and implications for marine reserve network design. Biol Rev Camb Philos Soc 90:1215-1247

* Grüss A, Kaplan DM, Guénette S, Roberts CM, Botsford LW (2011a) Consequences of adult and juvenile movement for marine protected areas. Biol Conserv 144:692-702

* Grüss A, Kaplan DM, Hart DR (2011b) Relative impacts of adult movement, larval dispersal and harvester movement on the effectiveness of reserve networks. PLOS ONE 6:e19960

*Herbig JL, Szedlmayer ST (2016) Movement patterns of gray triggerfish, Balistes capriscus, around artificial reefs in the northern Gulf of Mexico. Fish Manag Ecol 23: 418-427

Hernández JMR, Alvarado NP, Vélez KC, Nemeth R, Appeldoorn R, Shervette V (2019) Queen triggerfish Balistes vetula reproductive biology in US Caribbean waters. Trans Am Fish Soc 148:134-147

Heyman WD, Kjerfve B (2008) Characterization of transient multi-species reef fish spawning aggregations at Gladden Spit, Belize. Bull Mar Sci 83:531-551

Hilborn R, Stokes K, Maguire JJ, Smith T and others (2004) When can marine reserves improve fisheries management? Ocean Coast Manag 47:197-205

*Hitt S, Pittman SJ, Nemeth RS (2011) Diel movements of fishes linked to benthic seascape structure in a Caribbean coral reef ecosystem. Mar Ecol Prog Ser 427: 275-291

* Hussey NE, Kessel ST, Aarestrup K, Cooke SJ and others (2015) Aquatic animal telemetry: a panoramic window into the underwater world. Science 348:1255642

Ingram GW Jr, Patterson WF III (2001) Movement patterns of red snapper (Lutjanus campechanus), greater amberjack (Seriola dumeri), and gray triggerfish (Balistes capriscus) in the Gulf of Mexico and the utility of marine reserves as management tools. Proc Gulf Caribb Fish Inst 52:686-699

James D (2000) Diet, movement, and covering behavior of the sea urchin Toxopneustes roseus in rhodolith beds in the Gulf of California, México. Mar Biol 137:913-923

Jossart J, Nemeth RS, Primack A, Stolz R (2017) Extreme passive acoustic telemetry detection variability on a mesophotic coral reef, United States Virgin Islands. Mar Biol 164:180

Kadison E, Nemeth RS, Herzlieb S, Blondeau J (2006) Temporal and spatial dynamics of Lutjanus cyanopterus (Pisces: Lutjanidae) and L. jocu spawning aggregations in the United States Virgin Islands. Rev Biol Trop 54:69-78

Kadison E, Nemeth RS, Blondeau JE (2009) Assessment of an unprotected red hind (Epinephelus guttatus) spawning aggregation on Saba Bank in the Netherlands Antilles. Bull Mar Sci 85:101-118

Kadison E, Brandt M, Nemeth R, Martens J, Blondeau J, Smith T (2017) Abundance of commercially important reef fish indicates different levels of over-exploitation across shelves of the US Virgin Islands. PLOS ONE 12: e0180063 
Kawase K (2002) Simplicity and diversity in the reproductive ecology of triggerfish (Balistidae) and filefish (Monacanthidae). Fish Sci 68:119-122

Kendall MS, Monaco ME, Winship A (2016) Baffling telemetry detections can be useful: an acoustic receiver design to monitor organisms along reserve boundaries and ecotones. Anim Biotelem 4:2

Kendall MS, Siceloff L, Winship A, Monaco ME (2017) Determining conservation potential of an opportunistically defined MPA boundary using fish telemetry. Biol Conserv 211:37-46

Kerr LA, Secor DH (2012) Partial migration across populations of white perch (Morone americana): a flexible life history strategy in a variable estuarine environment. Estuaries Coasts 35:227-236

Kobara S, Heyman WD, Pittman SJ, Nemeth RS (2013) Biogeography of transient reef fish spawning aggregations in the Caribbean: a synthesis for future research and management. Oceanogr Mar Biol Annu Rev 51:281-326

Kramer DL, Chapman MR (1999) Implications of fish home range size and relocation for marine reserve function. Environ Biol Fishes 55:65-79

Krueck NC, Legrand C, Ahmadia GN, Estradivari and others (2018) Reserve sizes needed to protect coral reef fishes. Conserv Lett 11:e12415

Lauck T, Clark CW, Mangel M, Munro GR (1998) Implementing the precautionary principle in fisheries management through marine reserves. Ecol Appl 8:S72-S78

* Lobel PS, Johannes RE (1980) Nesting, eggs and larvae of triggerfish (Balistidae). Environ Biol Fishes 5:251-252

March D, Palmer M, Alós J, Grau A, Cardona F (2010) Shortterm residence, home range size and diel patterns of the painted comber Serranus scriba in a temperate marine reserve. Mar Ecol Prog Ser 400:195-206

Mathies NH, Ogburn MB, McFall G, Fangman S (2014) Environmental interference factors affecting detection range in acoustic telemetry studies using fixed receiver arrays. Mar Ecol Prog Ser 495:27-38

Mazeroll AI, Montgomery WL (1998) Daily migrations of a coral reef fish in the Red Sea (Gulf of Aqaba, Israel): initiation and orientation. Copeia 1998:893-905

* Meyer CG, Papastamatiou YP, Clark TB (2010) Differential movement patterns and site fidelity among trophic groups of reef fishes in a Hawaiian marine protected area. Mar Biol 157:1499-1511

Nemeth RS, Blondeau J, Herzlieb S, Kadison E (2007) Spatial and temporal patterns of movement and migration at spawning aggregations of red hind, Epinephelus guttatus, in the US Virgin Islands. Environ Biol Fishes 78 : 365-381

Newman D, Berkson J, Suatoni L (2015) Current methods for setting catch limits for data-limited fish stocks in the United States. Fish Res 164:86-93

Papastamatiou YP, Meyer CG, Carvalho F, Dale JJ, Hutchinson MR, Holland KN (2013) Telemetry and random walk models reveal complex patterns of partial migration in a large marine predator. Ecology 94:2595-2606

Payne NL, Gillanders BM, Webber DM, Semmens JM (2010) Interpreting diel activity patterns from acoustic telemetry: the need for controls. Mar Ecol Prog Ser 419:295-301

* Pittman SJ, Monaco ME, Friedlander AM, Legare B and others (2014a) Fish with chips: tracking reef fish movements to evaluate size and connectivity of Caribbean marine protected areas. PLOS ONE 9:e96028

Pittman SJ, Bauer L, Hile SD, Jeffrey CFG, Davenport E,
Caldow C (2014b) Marine protected areas of the U.S. Virgin Islands: ecological performance report. Tech Memo NOS NCCOS 187. NOAA, Silver Spring, MD

Popple I, Hunte W (2005) Movement patterns of Cephalopholis cruentata in a marine reserve in St Lucia, W.I., obtained from ultrasonic telemetry. J Fish Biol 67: 981-992

R Core Team (2016) R: a language and environment for statistical computing. R Foundation for Statistical Computing, Vienna

Randall JE (1967) Food habits of reef fishes of the West Indies. Stud Trop Oceanogr 5:665-847

Reid JM, Travis JM, Daunt F, Burthe SJ, Wanless S, Dytham C (2018) Population and evolutionary dynamics in spatially structured seasonally varying environments. Biol Rev Camb Philos Soc 93:1578-1603

* Reinthal PN, Kensley B, Lewis SM (1984) Dietary shifts in the queen triggerfish, Balistes vetula, in the absence of its primary food item, Diadema antillarum. Mar Ecol 5: 191-195

* Rhodes K, Mcllwain J, Joseph E, Nemeth R (2012) Reproductive movement, residency and fisheries vulnerability of brown-marbled grouper, Epinephelus fuscoguttatus (Forsskål, 1775). Coral Reefs 31:443-453

Robertson DR (1988) Extreme variation in settlement of the Caribbean triggerfish Balistes vetula in Panama. Copeia 1988:698-703

* Rowell TJ, Nemeth RS, Schärer MT, Appeldoorn RS (2015) Fish sound production and acoustic telemetry reveal behaviors and spatial patterns associated with spawning aggregations of two Caribbean groupers. Mar Ecol Prog Ser 518:239-254

* Russ GR, Alcala AC (2004) Marine reserves: long-term protection is required for full recovery of predatory fish populations. Oecologia 138:622-627

Sadovy de Mitcheson Y, Erisman B (2012) Fishery and biological implications of fishing spawning aggregations, and the social and economic importance of aggregating fishes. In: Sadovy de Mitcheson Y, Colin PL (eds) Reef fish spawning aggregations: biology, research and management. Springer, Dordrecht, p 225-284

Sagarese SR, Rios AB, Cass-Calay SL, Cummings NJ and others (2018) Working towards a framework for stock evaluations in data limited fisheries. N Am J Fish Manag 38:507-537

Sale PF, Cowen RK, Danilowicz BS, Jones GP and others (2005) Critical science gaps impede use of no-take fishery reserves. Trends Ecol Evol 20:74-80

* Schärer MT, Nemeth MI, Mann D, Locascio J, Appeldoorn RS, Rowell TJ (2012) Sound production and reproductive behavior of yellowfin grouper, Mycteroperca venenosa (Serranidae) at a spawning aggregation. Copeia 2012: 135-144

Selby TH, Hart KM, Fujisaki I, Smith BJ and others (2016) Can you hear me now? Range testing a submerged passive acoustic receiver array in a Caribbean coral reef habitat. Ecol Evol 6:4823-4835

Simmons CM, Szedlmayer ST (2012) Territoriality, reproductive behavior, and parental care in gray triggerfish, Balistes capriscus, from the northern Gulf of Mexico. Bull Mar Sci 88:197-209

Simpfendorfer CA, Heupel MR, Hueter RE (2002) Estimation of short-term centers of activity from an array of omnidirectional hydrophones and its use in studying animal movements. Can J Fish Aquat Sci 59:23-32 
Starr RM, Sala E, Ballesteros E, Zabala M (2007) Spatial dynamics of the Nassau grouper Epinephelus striatus in a Caribbean atoll. Mar Ecol Prog Ser 343:239-249

Stump K, Dahlgren CP, Sherman KD, Knapp CR (2017) Nassau grouper migration patterns during full moon suggest collapsed historic fish spawning aggregation and evidence of an undocumented aggregation. Bull Mar Sci 93:375-389

Topping DT, Szedlmayer ST (2011) Home range and movement patterns of red snapper (Lutjanus campechanus) on artificial reefs. Fish Res 112:77-84

Tuohy E, Nemeth MI, Bejarano I, Schärer MT, Appeldoorn RS (2015) In situ tagging of Nassau grouper Epinephelus striatus using closed-circuit rebreathers at a spawning aggregation in Puerto Rico. Mar Technol Soc J 49: 115-123

Turingan RG, Wainwright PC, Hensley DA (1995) Interpopulation variation in prey use and feeding biomechanics in Caribbean triggerfishes. Oecologia 102:296-304

Tyler J, Munroe T (2015) Balistes vetula. The IUCN Red List of Threatened Species 2015:eT2539A78554441

Udyawer V, Dwyer RG, Hoenner X, Babcock RC and others

Editorial responsibility: Janet Ley,

St. Petersburg, Florida, USA
(2018) A standardised framework for analysing animal detections from automated tracking arrays. Anim Biotelem 6:17

Weber J, Brown J (2009) Using lessons learned from six years of reef fish spawning aggregation site validation, collaboration, and outreach in St. Croix, USVI. Proc Gulf Caribb Fish Inst 61:320-323

Wheeks R, Green AL, Joseph E, Peterson N, Terk E (2017) Using reef fish movement to inform marine reserve design. J Appl Ecol 54:145-152

* Weiss HM, Lozano-Álvarez E, Briones-Fourzán P, NegreteSoto F (2006) Using red light with fixed-site video cameras to study the behavior of the spiny lobster, Panulirus argus, and associated animals at night and inside their shelters. Mar Technol Soc J 40:86-95

*Welsh J, Fox R, Webber D, Bellwood D (2012) Performance of remote acoustic receivers within a coral reef habitat: implications for array design. Coral Reefs 31:693-702

Zeller DC (1998) Spawning aggregations: patterns of movement of the coral trout Plectropomus leopardus (Serranidae) as determined by ultrasonic telemetry. Mar Ecol Prog Ser 162:253-263

Submitted: November 12, 2018; Accepted: March 22, 2019 Proofs received from author(s): April 29, 2019 